\title{
INFLATION AND NUMBER OF TAXABLE ENTREPRENEURS (NTE) TOWARDS ADMISSION OF VALUE ADDED TAX (VAT)
}

\author{
Rima Sundari \\ rima.sundari02@gmail.com \\ Fajar Maulana \\ Financial Accounting, Pos Indonesia Polytechnic \\ Jl. Sariasih No.54, Sarijadi, Sukasari, \\ Kota Bandung, Jawa Barat 40151 \\ received: 2/11/17; revised: 3/12/18; published: 31/12/18
}

\begin{abstract}
This study aims is to determine the effect of macroeconomic variables on inflation and the Number of Taxable Entrepreneurs (NTE) both partially and simultaneously on the receipt of Value Added Tax (VAT). This study uses a quantitative approach. The sampling technique used is purposive sampling. The sample in this study were 3 KPPs in West Java that are KPP Majalaya, KPP Sukabumi, and KPP Tasikmalaya with monthly data of the research period July 2013 - June 2016, the number of sample data used was 108, and analyzed using multiple regression analysis. The results of the study show that inflation partially has a negative and significant effect on VAT receipts. While simultaneously inflation, the number of NTE has a positive and significant effect on VAT receipts.
\end{abstract}

Keywords: inflation; the number of taxable entrepreneurs (NTE); value added tax (VAT)

\section{INTRODUCTION}

In the era of globalization, countries in the world are required to compete in all fields, including technology, information, culture, social, business, and economics. To face the era of globalization and global competition, the Indonesian government seeks to increase economic growth, as stipulated in the 2015-2019 National Medium-Term Development Plan (RPJMN) at an average of 7\% in five years and 5.2\% for 2016 in accordance with the target of the 2016 State Budget Amendment (APBN-P) (Kemenkeu. go.id). One of the government's efforts in increasing economic growth is by maximizing the potential in the field of tax revenue.

According to Constitution Number 28 of 2007 Third Amendment to Constitution No. 6 of 1983 concerning General Provisions and Tax Procedures Article 1 tax is a compulsory contribution to the stateowned by an individual or entity that is compelling under the constitution by not receiving compensation directly and used for the state's needs for the greatest prosperity of the people. The government is determined to optimize tax revenues and maximize state revenues from the taxation sector. As stated by Minister of Finance Sri Mulyani (2016) quoted from (detik. com), the importance of tax revenues as a source of development funding. The government will strive to optimize tax revenues while maintaining a healthy investment climate and encouraging business growth.

Figure 1 shows the tax has the biggest contribution to the source of state revenues, the percentage value is more dominant than other sources of state income such as PNBP, Customs \& Excise, and grants. However, the realization and achievement of the target have not been maximized. Within four years from 2013 to 2016 the achievement of tax revenues has decreased, so it does not reach the target. The phenomenon is shown in Table 1 and Figure 2.

According to Finance Minister Sri Mulyani (2016) quoted in (bisnis.liputan6.com), there are three things that cause tax revenues not to be in line with the government's target. First, national economic growth. Secondly, there has not been much improvement in commodity prices, especially those that are the mainstay of exports, which has also resulted in state revenues from the sector also falling. These low commodity prices contribute to state revenues of Rp 108 trillion. Third, global economic factors that have not yet recovered have an effect on the decline in international trade.

Based on data from Table 2, it is known that the source of the largest tax revenue is income tax. Then the second is the source of value-added tax. Value Added Tax (VAT) is the second largest source of tax revenue after Income Tax $(\mathrm{PPh})$ by providing around 
$33 \%$ of state tax revenues (Financial Note and 2014 Revised State Budget).

Realization of revenue from Value Added Tax from 2013-2016 continues to increase. However, its growth has decreased. This phenomenon can be shown in Figure 3.

Figure 3 shows growth and tax achievement experiencing a downward trend from 2013 to 2016. The decline in imports and economic slowdown is a factor in decreasing growth and achieving VAT revenues (www.pajak.go.id, 2015). A. Fuad Rachmany (2012) explains that lack of achievement of VAT receipts because the level of compliance of business actors in depositing VAT is still low. Then, there are still many transactions that are not recorded or known as underground economy, so that VAT receipts do not reach the target. There are still many institutions or institutions that have tax-related data that have not submitted data, especially since the information technology system has not yet reached the informal sector as a whole. VAT should be applied to all financial transactions but there are still many retail sector taxpayers that have not fulfilled their obligations.

Consumption activities for developing countries such as Indonesia are one of the main economic activities carried out, therefore increasing public consumption activities means that it will affect the amount of VAT revenues (Wijayanti and Firmansyah, 2015). Based on this phenomenon, it can be assumed that VAT has a close relationship with economic activities. Especially consumption activities carried out by the community.

Based on the theory above, VAT correlates with economic activity. Changes in the economic condition of a country will have an impact on the acceptance of Value Added Tax (VAT) of a country. The stability of a country's economy plays an important role in tax revenues. There are two factors that cause changes in economic stability are internal and external factors. External factors can be influenced by the macroeconomic conditions of a country. If a country's macro economy is unstable it will have an impact on the economic activities of the community. A country's macroeconomic fluctuations can have an impact on decreasing people's purchasing power, investment and export imports which will also have an impact on the receipt of a country's VAT (Renata et al, 2016). In this case, the macroeconomic component that can play an important role is the inflation rate. Inflation affects tax revenue where inflation is low due to the growth of state revenues along with the increasing consumption that occurs in society (Nalendra, 2014). Such a phenomenon in (Mody \& Carare, 2010). The increase in core inflation in Germany after the increase in VAT 2007 was smaller than expected, which led to speculation about the effects of inflation. tax increases contributed to two-thirds of the increase in core inflation in 2006-2007 at an estimated 73 percent.

In addition to macroeconomic variables such as inflation, there are several other variables that can affect the receipt of Value Added Tax (VAT). When viewed from the side of taxpayers, one of the variables that can affect VAT receipts is taxpayers who have been confirmed as Taxable Entrepreneurs (NTE). According to the Constitution of the Republic of Indonesia Number 18 of 2000 concerning the Second Amendment to Constitution Number 8 of 1983 concerning Value Added Tax on Goods and Services and Taxes and Sales Taxes on Luxury Goods. Taxable Entrepreneurs are entrepreneurs who in their business activities or work carry out Taxable Goods (BKP) and or delivery of Taxable Services (JKP) and / or exports of BKP that are taxed under the Value Added Tax (VAT) Constitution which is obliged to report their business to confirmed as NTE, not including small entrepreneurs, whose limits are determined by the Decree of the Minister of Finance, unless Small-scale Entrepreneurs choose to be confirmed as NTE. NTE is required to report its business and is obliged to collect, deposit and report the payable VAT (Constitution Number 42 of 2009 concerning Value Added Goods and Services Tax and Sales Tax on Luxury Goods).

Realization of tax revenues is not only supported by economic factors, but also non-economic factors. One of the non-economic factors that greatly influence tax revenues is the taxation policies taken by the Government, such as tax rates, non-taxable income (PTKP), and taxable income (NTE) (www.kemenkeu. go.id). The high number of PFM will have a positive impact on VAT receipts. As more and more PKPs eat, more and more individuals or agencies will deposit VAT with the Directorate General of Taxes and will influence the amount of VAT acceptance rates (Sentami et al. 2014). This phenomenon is similar to what was stated by Pandiangan (2014) The increase in taxpayers who establish themselves as NTE will increase the potential for taxation of VAT objects, which means it will increase the realization of VAT receipts.

The results of previous studies conducted by Muibi \& Sinbo (2013) showed that inflation had a significant effect on the receipt of Value Added Tax in Nigeria. While the results of previous studies relating to the relationship between NTE and Tax Revenue have been carried out by Sentami (2014) explaining that registered NTE has a positive and significant effect on VAT Receipt, in other words, the higher the Amount of Taxable Entrepreneurs, the higher the VAT Receipt or vice versa.

The existence of gap phenomena and research gap of previous research which is the reason for researchers to conduct research on the effect of inflation and the number of Taxable Entrepreneurs (NTE) on VAT receipts. Research conducted by the author was conducted at the Regional Office of the Directorate 
General of Taxation (DGT) of West Java I whose work area covered all areas in West Java.

According to Karya and Syamsuddin (2016: 12) Inflation is defined as rising prices for all goods continuously. The characteristics of inflation are the amount of money in circulation more than the number of goods circulating, which is indicated by Aggregate Demand (D) greater than Aggregate Supply) (US). Prices tend to rise continuously. Thus, if the price rises only immediately and then falls back or in other words the price rises not continuously, then inflation cannot be said. And the exchange rate of money has decreased.

Definition of value added tax according to Mardiasmo (2013: 273) is a tax imposed on each value added of goods or services in circulation from producers to consumers. The VAT Tax Subject is a Taxable Person for VAT purposes (NTE), that is an individual or entity, including a government agency in the environment of the company or whose job is to deliver BKP and/or JKP and export BKP Mardiasmo (2016: 269) states that when viewed from its history, value-added tax is a substitute for Sales Tax. The reason for this understanding is that Sales Tax is deemed to be no longer sufficient to accommodate community activities and has not yet reached the target of development needs, including increasing state revenues, encouraging exports, and distributing taxation.

According to Sukardji (2014: 170) taxable entrepreneurs are entrepreneurs who submit taxable goods (BKP) or surrender of taxable services (JKP) not including small entrepreneurs whose limits are set by the Minister of Finance. UU KUP Number 28 of 2007 Article 2 paragraph (2) reads Every Taxpayer as an Entrepreneur who is taxed according to the 1984 VAT Constitution and its amendments, is obliged to report his business at the Office of the Directorate General of Taxes whose area of work covers the place of residence or place of business of the Entrepreneur and place of activity business to be confirmed as a Taxable Entrepreneur (NTE).

Inflation occurs if demand is greater than supply and results in rising prices. Inflation has a large influence on economic conditions. Fluctuating and persistent changes in inflation can affect economic balance and stability globally, including economic actors. The effect of rising inflation coupled with the length of the distribution channel will cause the price of goods and services to increase, this will have an impact on purchasing power and transactions of goods and services that will reduce VAT receipts (Sinaga, 2010: 25). As in Pudenz's research, Joseph Raymond (2010). This study shows that value-added tax, together with the complete elimination of corporate income tax and a reduction in personal income tax by $50 \%$, will continue to increase tax revenues and allow the
United States to better handle its high national debt. Based on the explanation, the hypotheses formulated. There is a significant effect between inflation on valueadded tax (VAT).

According to Siti Resmi (2014: 83) that Taxable Entrepreneurs (NTE) if the decrease in the level of consumer consumption will affect the condition of Value Added Tax Receipts. According to Prasetyono (2012: 134) states that Taxable Entrepreneurs must report the amount of tax that has been made tax invoices to the state treasury or entered as Value Added Tax Receipts. According to Waluyo (2012: 253) that the level of compliance from registered NTEs and newly registered through the implementation of extensification programs is expected to increase so that value-added tax revenues will also increase. Based on the explanation, the hypotheses formulated. There is a significant influence between the number of taxable entrepreneurs on value-added tax revenue (VAT).

There are several factors that cause changes in tax revenues, especially the receipt of Value Added Tax discussed in this study. These factors can be either internal or external factors. External factors can be influenced by the macroeconomic conditions of a country. If a country's macroeconomy is unstable, it will have an impact on the economic activities of the community which will have an impact on a country's tax revenues. A country's macroeconomic fluctuations can have an impact on decreasing people's purchasing power, investment and export imports which will also have an impact on the receipt of a country's VAT (Renata et al, 2016). In this case, the macroeconomic component that can play an important role is the inflation rate. Inflation affects tax revenue where inflation is low due to the growth of state revenues along with the increasing consumption that occurs in society (Nalendra, 2014). In other words, a high inflation rate will reduce the purchasing power of consumers. Therefore, public consumption activities which are objects of VAT will decrease. Thus, inflation can affect VAT receipts. Whereas internal factors are in the form of Tax Policy (Tax Policy), Tax Administration (Tax Administration), and Tax Regulations (Tax Constitution). One form of tax policy is tax intensification and extensification program. With the extensification program, you can get additional registered taxpayers and the addition of Taxable Entrepreneurs (NTE) so that they can increase tax revenues. Based on the explanation, the hypothesis formulated. There is a simultaneous and significant influence between inflation and the number of taxable entrepreneurs (NTE) on value-added tax (VAT).

\section{METHODS}

The unit of analysis and the object examined in this study were the West Java Regional Office of DGT 
I with the research period July 2013 - June 2016. This study using the method of documentation and literature study. The inflation rate data is obtained from the official Bank Indonesia website, www.bi.go. id. Data on the number of taxable entrepreneurs and the realization of value added tax receipts obtained from the West Java Regional Tax Office I during the period July 2013 - June 2016.

Indicator for measuring inflation is the Consumer Price Index (CPI). The inflation data used in this study is monthly data, the period July 2013-June 2016. Measurement of inflation uses units of percent. Indicator Taxable entrepreneurs are the number of taxable entrepreneurs who submit taxable goods (BKP) and surrender of taxable services (JKP). The number of PFM data used in this study is monthly data, the period July 2013 - June 2016. The VAT receipt data used in this study is monthly data, the period July 2013 - June 2016.

The population is inflation data, the number of PFM and the number of VAT receipts throughout the work area of the West Java Regional Office of DGT I. The sampling technique used is nonprobability sampling with a sampling technique that is purposive sampling. The 3 Primary KPPs that were sampled were KPP Pratama Sukabumi, KPP Pratama Tasikmalaya and KPP Pratama Majalaya with monthly data numbers during the period July 2013 - June 2016, the number of sample data was 108 observations.

The normality test of the data is intended to test whether the regression model of the confounding or residual variables has a normal distribution. In this study, the normality test used Kolmogorov-Smirnov (1-Sample K-S). If p-value $>0.05$, the data is declared to be normally distributed (Ghozali, 2013: 165). The researcher used the normality test to test data that were normally distributed.

Multicollinearity test aims to examine whether the regression model found a correlation between independent variables. The author uses this test because in this study there are two independent variables. A good regression model should not have a correlation between independent variables (Ghozali, 2013: 105).

The author uses Statistical for the Social Science (SPSS) computer application program version 23 as a research analysis tool. The regression equation developed in this study is:

$$
\mathrm{Y}=\mathrm{a}+\mathrm{b}_{1} \mathrm{X}_{1}+\mathrm{b}_{2} \mathrm{X}_{2}
$$

$$
\begin{array}{ll}
\mathrm{Y} & =\text { VAT receipts } \\
\mathrm{a} & =\text { Number } \mathrm{Y} \text { if } \mathrm{X}=0 \text { (constant) } \\
\mathrm{X}_{1} & =\text { Inflation } \\
\mathrm{X}_{2} & =\text { NTE } \\
\mathrm{b}_{1}, \mathrm{~b}_{2} & =\text { Regression Coefficient variable } \mathrm{X}_{1}, \mathrm{X}_{2}
\end{array}
$$

Based on Table 3 the results of testing the Kolmogorov-Smirnov Normality test above, it is known that the significance value ( $\mathrm{p}$-value) is 0.200 . So that it can be seen that $0.200>0.05$ ( $\mathrm{p}$-value $>$ 0.05 ). According to Ghozali (2013) if p-value $>0.05$ then the data is declared to be normally distributed. So that it can be concluded that the data tested in this study shows the data residuals are normally distributed and the regression model has met the assumption of normality.

Based on Table 4, it is known that the value of the Tolerance variable Inflation $\left(\mathrm{X}_{1}\right)$ and NTE $\left(\mathrm{X}_{2}\right)$ is $0.883>0.10$. Meanwhile, the VIF value of the inflation variable $\left(\mathrm{X}_{1}\right)$ and NTE $\left(\mathrm{X}_{2}\right)$ is $1,133<10.00$. The cut-off value commonly used to indicate the presence of multicollinearity is the Tolerance Value $\leq 0.10$ or equal to the VIF value $\geq 10$ (Ghozali, 2013: 105). So it can be concluded that the regression model in this study is free from multicollinearity.

Based on Table 5, the regression equation model as follows:

$$
\begin{aligned}
\mathrm{Y}= & 15981147363,614-722083035,606 \mathrm{X}_{1}+ \\
& 234527952,398 \mathrm{X}_{2} \ldots \ldots \ldots \ldots \ldots \ldots \ldots \ldots \ldots \ldots \ldots . . . \cdots \\
& \ldots .(2)
\end{aligned}
$$

The results of $p$-value $<0.05$. This means that there is a partially significant influence between inflation on value-added tax (VAT) and partially the amount of NTE on value-added tax (VAT).

Based on the results of the F test (Table 6) it shows that the $p$-value is 0,000 , meaning that there is a simultaneous significant influence between inflation and the NTE on value added tax (VAT).

Based on the results of the multiple correlation analysis shown in the R number of 0.662 , it shows that the correlation or relationship between inflation $\left(X_{1}\right)$ and NTE $\left(\mathrm{X}_{2}\right)$ on VAT receipts $(\mathrm{Y})$ is strong because it is in the interval of $0.60-799$. Meanwhile based on the results of the coefficient of determination in Table 7. shows that the Adjusted R Square coefficient is 0.427 or $42.7 \%$. This shows that $42.7 \%$ of the dependent variable (VAT receipts) can be explained by the independent variable (inflation and total NTE), while the rest $(100 \%-42.7 \%=57.3 \%)$ is explained by other reasons outside the model or other variables beyond those examined in this study.

\section{DISCUSSION}

Based on the results of the study it is known that there is a partially significant influence between inflation on value-added tax (VAT). The results of this study support the previous research which stated that inflation partially had a significant negative effect on VAT receipts conducted by Sinaga (2010), Muibi 
\& Sinbo (2013) and Arifin (2015). This is because inflation can change the pattern of allocation of production factors. This change can occur through a number of decreases in the demand for various types of goods affected by inflation which can then lead to changes in the production of certain items. The effect of rising inflation coupled with the length of the distribution channel will cause the price of goods and services to increase, this will have an impact on purchasing power and transactions of goods and services that will reduce VAT receipts (Sinaga, 2010). Then in accordance with Wijayanti's theory (2015: 23) which states that consumption activities for developing countries such as Indonesia are one of the main economic activities carried out, therefore increasing public consumption activities means that it will affect the number of VAT receipts. So, if high inflation causes the purchasing power of the people to be low, causing consumption activities for goods to be taxable decreases. So this will affect the decreasing amount of VAT receipts.

Based on the results of the study, it is known that there is a partially significant effect between the NTE on value-added tax (VAT). These results support the previous research which stated that the number of NTE proved to have a partially significant effect on VAT receipts conducted by Renata, et al (2016), Sentami (2014), Nuraeni (2011), Pandiangan (2014), Seftianne \& Handayani (2011), Masithoh (2011), Saepudin (2008) and Aditya (2009). This is because NTE is a Taxpayer who submits Taxable Goods and/ or Taxable Services that are taxed according to the 1984 VAT constitution and its amendments. DGT's additional number can be taken by extending taxes based on internal and external data so that if there is a NTE that does not report its business activities, office inauguration can be issued. Where there is an increase in the number of NTE, there is a surrender of goods and services subject to tax which is an object of VAT . The greater the number of NTE, the greater the VAT object, which means that the VAT receipt will be greater. DGT receipts can also be increased by the DGT through tax intensification, namely by testing NTE compliance that has been registered as well as from the results of extensification so that NTE is not only registered but also carries out its rights and obligations (Nuraeni, 2011). So it means that with the addition of NTE activities, the VAT object will be greater because of the increase in the delivery of taxable goods and services that will increase the acceptance of Value Added Tax (VAT).

Based on the results of the study it is known that there is a simultaneous significant effect between inflation and the NTE on value-added tax (VAT). These results support previous studies conducted by Renata, et al (2016), Saepudin (2008), Aditya (2009), Sentami (2014), and Nuraeni (2011). This is because there are several factors that cause changes in tax revenues, especially the receipt of Value Added Tax discussed in this study. These factors can be either internal or external factors. External factors can be influenced by the macroeconomic conditions of a country. If a country's macroeconomy is unstable, it will have an impact on the economic activities of the community which will have an impact on a country's tax revenues. A country's macroeconomic fluctuations can have an impact on decreasing people's purchasing power, investment and export imports which will also have an impact on the receipt of a country's VAT (Renata et al, 2016). In this case, the macroeconomic component that can play an important role is the inflation rate. Inflation affects tax revenue where inflation is low due to the growth of state revenues along with the increasing consumption that occurs in society (Nalendra, 2014). In other words, a high inflation rate will reduce the purchasing power of consumers. Therefore, public consumption activities which are objects of VAT will decrease. Thus, inflation can affect the decline in VAT receipts. Whereas internal factors are in the form of Tax Policy (Tax Policy), Tax Administration (Tax Administration), and Tax Regulations (Tax Constitution). One form of tax policy is tax intensification and extensification program. tax extensification is carried out by extending the tax base, for example through increasing the number of registered NTE (Manurung et, al., 2001 in Nuraeni 2011). With the extensification program, you can obtain additional registered taxpayers and the addition of Taxable Entrepreneurs (NTE) so that they can increase tax revenues.

\section{CONCLUSION}

Based on the studies that have been examined in this study, the researchers concluded several statements as follows: (1) Partially Inflation has a significant negative effect on VAT receipts; (2) Partially the number of NTE has a significant positive effect on VAT receipts; (3) Inflation and the number of PFM have a simultaneous and significant effect on VAT receipts.

\section{REFERENCES}

Aditya, R., 2015. Pengaruh pelatihan terhadap kompetensi dan kinerja karyawan (studi pada karyawan PT. PLN (Persero) distribusi Jawa Timur Area Malang). Jurnal Administrasi Bisnis, 27(2).

Arifin, M.A., 2015. Analisis Pengaruh Faktor Fundamental Internal Dan Eksternal Terhadap Harga Saham Perusahaan Sektor Perbankan Di Bursa Efek Indonesia. Jurnal Media Wahana Ekonomika, 9(2).

Bank Indonesia. 2017. Pengenalan Inflasi. Jakarta: 
Bank Indonesia. (http://www.bi.go.id/id/moneter/ inflasi/pengenalan/Contents/Default.aspx, accessed on April 15, 2016).

Constitution of the Republic of Indonesia Number 11 of 1994 concerning Amendments to Constitution Number 8 of 1983 concerning Value Added Tax on Goods and Services and Sales Tax on Luxury Goods.

Constitution of the Republic of Indonesia Number 18 of 2000 concerning Second Amendment to Constitution Number 8 of 1983 concerning Value Added Tax on Goods and Services and Sales Tax on Luxury Goods.

Constitution of the Republic of Indonesia Number 28 of 2007 The third amendment to Constitution Number 6 of 1983 concerning General Provisions and Tax Procedures.

Constitution of the Republic of Indonesia Number 8 of 1983 concerning Value Added Tax on Goods and Services and Sales Tax on Luxury Goods.

Constitution Number 16 of 2000 concerning General Provisions and Tax Procedures.

Constitution of the Republic of Indonesia number 42 of 2009 concerning Third Amendment to Constitution Number 8 of 1983 concerning Value Added Tax on Goods and Services and Sales Tax on Luxury Goods.

Constitution of the Republic of Indonesia Number 18 of 2000 concerning Second Amendment to Constitution Number 8 of 1983 concerning Value Added Tax on Goods and Services and Taxes and Sales Tax on Luxury Goods.

Constitution of the Republic of Indonesia Number 28 of 2007 concerning Third Amendment to Constitution Number 6 of 1983 concerning General Provisions and Tax Procedures.

Constitution of the Republic of Indonesia Number 9 of 1994 concerning Amendments to Constitution Number 6 of 1983 concerning General Provisions and Procedures for Taxation.

Deny, Septian. 2016. Sri Mulyani Ungkap Sebab Penerimaan Pajak 2016 Sulit Tercapai. (Online), (http://bisnis.liputan6.com/read/2570077/srimulyani-ungkap-sebab-penerimaan-pajak-2016sulit-tercapai, Accessed on March 7, 2017).

Directorate General of Tax, Ministry of Finance. 2014. Study of the Impact of Changes in Taxation Policies on Potential Sectoral Tax Revenues. Jakarta: The Directorate General of Tax, Ministry of Finance, (Online), (http://www.kemenkeu.go.id/ en/node/40988, accessed on March 9, 2017).

Directorate General of Tax, Ministry of Finance. 2015. Realization of Tax Revenue as of 31 August 2015. Jakarta: Directorate General of Tax, Ministry of Finance. (Online), (http://www.pajak. go.id/content/realization-penerimaan-pajak-31agustus-2015, accessed on March 8, 2017).
Director General of Taxes: There are 7 Strategic Steps to Securing Tax Revenue, (Online), (http://citasco. $\mathrm{com} / \mathrm{citasco} /$ $\mathrm{mod}=$ berita\&page $=$ show\&id $=1185$ $6 \& \mathrm{q}=\& \mathrm{hlm}=482$, accessed March 8, 2017).

Fuad Rachmany. 2012. Dirjen Pajak 'Paksa'Aparat Pajak Tingkatkan Kualitas. Diakses melalui www. detik.com

Ghozali, Imam. 2013. Aplikasi Analisis Multivariate dengan Program IMB SPSS 21. Semarang: Badan Penerbit Universitas Dipenogoro.

Idris, Muhammad .2016. JK: Target Pajak Tak Tercapai, Kenapa?. (Online), (https://finance. detik.com/ekonomi-bisnis/3088484/jk-targetpajak-tak-tercapai-kenapa, Accessed on March 8, 2017).

Karya, Detri \& Sayamsuddin, Syamri. 2016. Makroekonomi: Pengantar untuk Manajemen. Depok: PT. Rajagrafindo Persada.

Kementerian Keuangan. 2012. Nota Keuangan dan APBN Perubahan Tahun 2012. Jakarta: Kementerian Keuangan. (Online),(http://www. kemenkeu.go.id/node/30156, Accessed on March 7, 2017).

Kementerian Keuangan. 2013. Nota Keuangan dan RAPBN Perubahan Tahun 2013. Jakarta: Kementerian Keuangan. (Online), (http://www. kemenkeu.go.id/node/30158, Accessed on March 7, 2017).

Kementerian Keuangan. 2014. Nota Keuangan dan APBN Perubahan Tahun 2014. Jakarta: Kementerian Keuangan. (Online), http://www. kemenkeu.go.id/Data/nota-keuangan-apbnp-2014, Accessed on March 7, 2017).

Kementerian Keuangan. 2015. Nota Keuangan dan APBN Perubahan Tahun 2015. Jakarta: Kementerian Keuangan. (Online), http://www. kemenkeu.go.id/Data/nota-keuangan-apbn-ptahun-2015, Accessed on March 7, 2017).

Kementerian Keuangan. 2015. Nota Keuangan dan APBN Tahun 2015. Jakarta: Kementerian Keuangan.(Online, (http://www.kemenkeu.go.id/ node/30156, Accessed on March 8, 2017).

Kementerian Keuangan. 2016. Nota Keuangan dan APBN Perubahan Tahun 2016. Jakarta:KementerianKeuangan.(Online),(http:// www.kemenkeu.go.id/Data/nota-keuangan-apbnp-tahun-2016 Accessed on March 7, 2017).

Mardiasmo. 2013. Perpajakan Edisi Revisi Tahun 2013. Yogyakarta : Penerbit Andi.

Mardiasmo. 2016. Perpajakan Edisi Terbaru. Yogyakarta: Andi.

Masithoh, A.A. 2011. Pengaruh Penambahan Pengusaha Kena Pajak, Surat Pemberitahuan Masa PPN yang dilaporkan, dan Surat Setoran Pajak yang dilaporkan terhadap Penerimaan Pajak Pertambahan Nilai di KPP Pratama Semarang Candisari, Tesis Universitas Negeri 
Semarang. (tidak dipublikasikan).

Mody, M.A. and Carare, M.A., 2010. Spillovers of Domestic Shocks: Will They Counteract the" great Moderation"? (No. 10-78). International Monetary Fund.

Muibi \& Sinbo. 2013. Macroeconomic Determinants of Tax Revenue in Nigeria (1970-2011). World Applied Sciences Journal 28 (1): 27-35.

Nalendra, Encep Herdiana. 2014. Pengaruh Produk Domestik Regional Bruto (PDRB) Dan Tingkat Inflasi Terhadap Penerimaan Pajak (Survei Pada Provinsi Jawa Barat Periode 2008-2012). Skripsi. Bandung : Universitas Komputer Indonesia, (Online), (http://elib.unikom.ac.id/, accessed on March 9, 2017).

Nuraeni. 2011. Pengaruh Inflasi, Nilai Tukar Rupiah dan Jumlah Pengusaha Kena Pajak (PKP) terhadap penerimaan Pajak Pertambahan Nilai. UIN,Jakarta, 2011.

Pandiangan, Dedy. 2014. Pengaruh Surat Ketetapan Pajak Kurang Bayar, Surat Tagihan Pajak, Jumlah Pengusaha Kena Pajak dan Surat Pemberitahuan Terhadap Penerimaan Pajak Perambahan Nilai (VAT). Skripsi. Yogyakarta: Universitas Atma Jaya.

Peraturan Menteri Keuangan Republik Indonesia Nomor: 197/PMK.03/2013.

Peraturan Menteri Keuangan 68/PMK.03/2010 : Batasan Pengusaha Kecil Pajak Pertambahan Nilai.

Prasetyono, Dinar Sunar. 2012. Buku Pintar Pajak. Jakarta: Laksana.

Pudenz, Joseph Raymond. (2010). The Value-Added tax: Effects on tax revenue, U.S. Corporations, and individual taxpayers. (2010). Gross domestic product: Fourth quarter 2009 (Third Estimate). Washington, D.C.: United States Department of Commerce.

Putra, Alex Sentami. (2014). Effect of Total Taxable Entrepreneurs (PFM), Income Per Capita, Inflation, and Economic Growth of Revenue Service Tax VAT Office Pekanbaru. JOM FEKON Vol. 1 no. 2 Oktober 2014: 1-15.
Renata, dkk. 2016. Pengaruh Inflasi, Nilai Tukar Rupiah Dan Jumlah Pengusaha Kena Pajak Terhadap Penerimaan Pajak Pertambahan Nilai (Studi pada Kantor Wilayah DGT Jawa Timur I). Jurnal Perpajakan (JEJAK),(Online), Vol.9,No.1,2016:1-9, (perpajakan.studentjournal. ub.ac.id/index.php/perpajakan/article/view/263, accessed on March 8, 2017).

Resmi, Siti. 2014. Perpajakan Teori dan Kasus Edisi 8. Jakarta : Penerbit Salemba Empat.

Saepudin. 2008. Analisis Pengaruh Inflasi dan Nilai Tukar Rupiah Terhadap Penerimaan PPN Pada Kanwil DJP Jakarta Selatan. Jakarta: Fakultas Ekonomi dan Ilmu Sosial UIN Syarif Hidayatullah

Seftianne dan Handayani, Ratih. 2011. FaktorFaktor yang Mempengaruhi Struktur Modal pada Perusahaan Publik Sektor Manufaktur. Jurnal Bisnis dan Akuntansi 13 (1): 39-56.

Sinaga, M.S., 2018. Analysis of Influence of Tariff of Import Duty, Exchange Rate, Import Value And Import Volume on Income of Import Duty In Indonesia With Free Trade Agreement (FTA) As Moderating Variable. International Journal of Public Budgeting, Accounting and Finance, $1(2)$, pp.8-8.

Statistics Indonesia. 2017. Combined Annual Inflation of 7 Cities in West Java Province, 2008-2016. Bandung: Statistics Indonesia (https://jabar.bps. go.id/linkTableDinamis/view/id/20, accessed on March 9, 2017).

Sukardji, Untung. 2014. Pajak Pertambahan Nilai. Jakarta : PT. Raja Grafindo Persada.

Waluyo. 2012. Perpajakkan Indonesia. Jakarta : Penerbit Salemba Empat.

Wijayanti, Amalia, dan Firmansyah. 2015. Analisis Penerimaan Pajak Indonesia:Pendekatan Ekonomi Makro. Skripsi. Semarang: Fakultas Ekonomika Dan Bisnis Universitas Diponegoro, (Online), (http://eprints.undip.ac.id/46504/, accessed on March 8, 2017).

www.wikipedia.org/wiki/Direktorat_Jenderal_Pajak, accessed on June 10, 2017). 
Percentage of State Revenue

APBN 2006

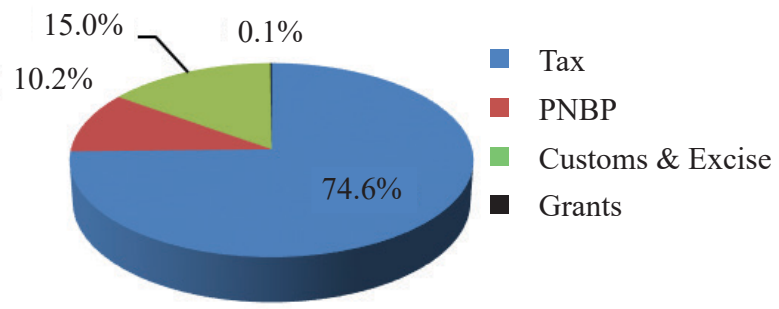

Source: Ministry of Finance (Data processed)

Figure 1. Percentage of State Revenue APBN 2016

Achievement of Revenue Realization VAT in 2013-2016

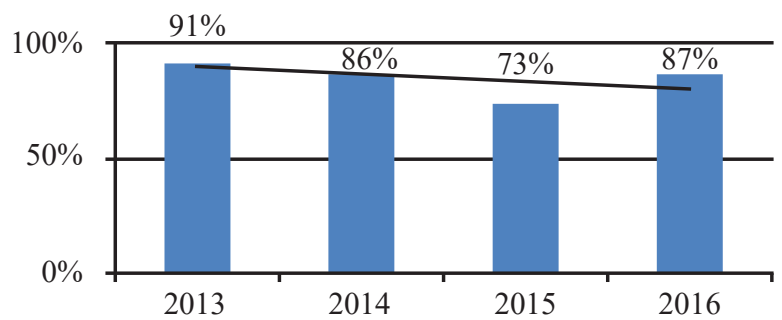

Source: Financial Note and APBN-P 2013-2016 (Data processed)

Figure 3. Achievement of Revenue Realization VAT in 2013-2016

Table 1. Percentage of Achievement of Realized

Tax Revenue 2013-2016

(In Billion Rupiah)

\begin{tabular}{cccc}
\hline Year & Realization & APBN-P & Achievement \\
\hline 2013 & $\mathrm{Rp} 1.077 .306,70$ & $\mathrm{Rp} 1.139 .348,30$ & $94,6 \%$ \\
2014 & $\mathrm{Rp} 1.146 .865,80$ & $\mathrm{Rp} 1.246 .107,00$ & $92,0 \%$ \\
2015 & $\mathrm{Rp} 1.240 .418,86$ & $\mathrm{Rp} 1.489 .255,50$ & $83,3 \%$ \\
2016 & $\mathrm{Rp} 1.105 .000,00 *$ & $\mathrm{Rp} 1.539 .166,20$ & $71,8 \%$
\end{tabular}

Information: *unaudited

Source: Financial Note and APBN-P 2013-2016 (Data processed)

Table 2. Realization of Indonesian Tax Revenue from 2013-2016 (In Trillion Rupiah)

\begin{tabular}{|c|c|c|c|c|}
\hline Source of Acceptance & 2013 & 2014 & 2015 & $2016^{*}$ \\
\hline Income Tax & Rp506 & Rp546 & Rp602 & Rp855 \\
\hline Value-Added Tax & Rp384 & Rp409 & Rp423 & Rp474 \\
\hline Property Tax & $\operatorname{Rp} 25$ & Rp23 & Rp29 & Rp17 \\
\hline Customs For Land and & - & - & - & - \\
\hline \multicolumn{5}{|l|}{ Building Rights } \\
\hline Excise & Rp108 & Rp118 & Rp144 & Rp148 \\
\hline Other Taxes & Rp4 & Rp6 & Rp5 & Rp7 \\
\hline International Trade Tax & Rp47 & Rp43 & Rp34 & Rp35 \\
\hline Import Duty & Rp31 & Rp32 & Rp31 & Rp33 \\
\hline Export Tax & Rp15 & Rp11 & Rp3 & $\mathrm{Rp} 2$ \\
\hline Amount of Tax Revenue & Rp1.077 & Rp1.146 & Rp1.240 & Rp1.539 \\
\hline
\end{tabular}

Information: *APBNP 2016

Source: Financial Note and APBN-P 2013-2016 (www.kemenkeu.go.id)
Trends in Achieving Targets for Realization of Tax Revenues 2013-2016 (Billion Rupiah)

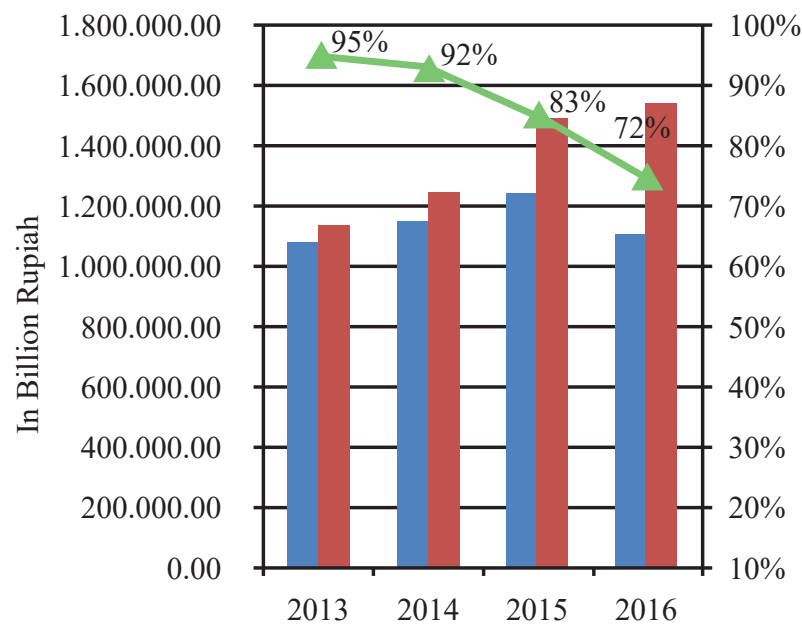

Source: Data processed

Figure 2. Trends in Achieving Targets for Realization of Tax Revenues 2013-2016

Table 3. Results of the Normality Test of Kolmogorov-Smirnov

\begin{tabular}{|c|c|c|}
\hline \multicolumn{3}{|c|}{ One-Sample Kolmogorov-Smirnov Test } \\
\hline & & Unstandardized Residua \\
\hline \multicolumn{2}{|l|}{$\mathrm{N}$} & 108 \\
\hline \multirow{2}{*}{$\begin{array}{l}\text { Normal } \\
\text { Parameters }^{\mathrm{a}, \mathrm{b}}\end{array}$} & Mean &,- 0000001 \\
\hline & Std. Deviation & 3580128550,66948130 \\
\hline \multirow{3}{*}{$\begin{array}{l}\text { Most Extreme } \\
\text { Differences }\end{array}$} & Absolute & 056 \\
\hline & Positive &, 056 \\
\hline & Negative &,- 035 \\
\hline \multicolumn{2}{|l|}{ Test Statistic } & 056 \\
\hline \multicolumn{2}{|c|}{ Asymp. Sig. (2-tailed) } & $200^{\mathrm{c}, \mathrm{d}}$ \\
\hline
\end{tabular}

a. Test distribution is Normal.

b. Calculated from data.

c. Lilliefors Significance Correction.

d. This is a lower bound of the true significance.

Table 4. Multicollinearity Test Results

Coefficients $^{\mathrm{a}}$

\begin{tabular}{llcc}
\hline \multirow{2}{*}{ Model } & \multicolumn{2}{c}{ Collinearity Statistics } \\
\cline { 3 - 4 } & Inflasi & Tolerance & VIF \\
\hline \multicolumn{2}{c}{1} &, 883 & 1,133 \\
& Jumlah_NTE &, 883 & 1,133 \\
\hline
\end{tabular}

a. Dependent Variable: Penerimaan_VAT 
Table 5. Results of Multiple Linear Regression Analysis

\begin{tabular}{|c|c|c|c|c|c|}
\hline \multicolumn{6}{|c|}{ Coefficients $^{\mathrm{a}}$} \\
\hline & & & \multirow{3}{*}{$\begin{array}{c}\text { Standardized } \\
\text { Coefficients } \\
\text { Beta } \\
\end{array}$} & \multirow[b]{3}{*}{$\mathrm{T}$} & \multirow[b]{3}{*}{ Sig. } \\
\hline \multirow[b]{2}{*}{ Model } & \multicolumn{2}{|c|}{ Unstandardized Coefficients } & & & \\
\hline & $\mathrm{B}$ & Std. Error & & & \\
\hline 1 (Constant) & 15981147363,614 & 1822354082,849 & & 8,770 &, 000 \\
\hline Inflasi & $-722083035,606$ & 215273731,445 &,- 261 & $-3,354$ &, 001 \\
\hline Jumlah_NTE & 234527952,398 & 34799915,821 &, 525 & 6,739 &, 000 \\
\hline
\end{tabular}

Table 6. F Test Result

ANOVA $^{\mathrm{a}}$

\begin{tabular}{|c|c|c|c|c|c|c|}
\hline Mode & & Sum of Squares & Df & Mean Square & $\mathrm{F}$ & Sig. \\
\hline \multirow[t]{3}{*}{1} & Regression & 1067100248103106600000,000 & 2 & 533550124051553300000,000 & 40,849 &, $000^{\mathrm{b}}$ \\
\hline & Residual & 1371453287007107700000,000 & 105 & 13061459876258169000,000 & & \\
\hline & Total & 2438553535110214300000,000 & 107 & & & \\
\hline
\end{tabular}

a. Dependent Variable: Penerimaan_VAT

b. Predictors: (Constant), Jumlah_NTE, Inflasi

Table 7. Results of the Determination Coefficient

\begin{tabular}{lcccc}
\multicolumn{4}{c}{ Model Summary } \\
\hline Model & $\mathrm{R}$ & $\mathrm{R}$ & $\begin{array}{c}\text { Adjusted } \\
\text { Square }\end{array}$ & $\begin{array}{c}\text { Std. Error of the } \\
\text { R Square }\end{array}$ \\
\hline 1 &, $662^{\mathrm{a}}$ &, 438 &, 427 & 3614064177,10839 \\
\hline a. Predictors: (Constant), Jumlah_NTE, Inflasi
\end{tabular}

